\title{
The Significant Role of Cyclin D1 in the Synergistic Growth-inhibitory Effect of Combined Therapy of Vandetanib with 5-Fluorouracil for Gastric Cancer
}

\author{
KAZUNORI YAWATA ${ }^{1}$, SHINJI OSADA ${ }^{2}$, TOSHIYUKI TANAHASHI ${ }^{1}$, SATOSHI MATSUI ${ }^{2}$, \\ YOSHIYUKI SASAKI ${ }^{1}$, YOSHIHIRO TANAKA ${ }^{1}$, NAOKI OKUMURA ${ }^{1}$, NOBUHISA MATSUHASHI ${ }^{1}$, \\ TAKAO TAKAHASHI ${ }^{1}$, KAZUYA YAMAGUCHI ${ }^{1}$ and KAZUHIRO YOSHIDA ${ }^{1}$ \\ Departments of ${ }^{1}$ Surgical Oncology, and ${ }^{2}$ Multidisciplinary Therapy for Hepato-Biliary-Pancreatic Cancer, \\ Gifu University Graduate School of Medicine, Gifu, Japan
}

\begin{abstract}
Background: 5-Fluorouracil (5-FU) has been a mainstay of chemotherapy for gastric cancer. Vandetanib is a tyrosine kinase inhibitor with inhibitory activity against vascular endothelial growth factor receptor and epidermal growth factor receptor (EGFR). We investigated the combination effect of vandetanib with 5-FU on gastric cancer cells. Materials and Methods: Anticancer efficacy was assessed by 3-(4,5-dimethyl-2-tetrazolyl)-2,5-diphenyl$2 \mathrm{H}$ tetrazolium bromide assay of five gastric cancer cell lines, MKN1, MKN7, MKN45, MKN74, and TMK1. Signal expression was examined by western blot, and the cell-cycle distribution was assessed by flow cytometry. In vivo anticancer activity of vandetanib with/without 5-FU was tested in MKN74 cells on nude mice. Results: Vandetanib inhibited the growth of all cell lines. In MKN7 and MKN74 cells, the combination of 5-FU and vandetanib had synergistic effects, but effects were only additional against the other cell lines in vitro. Combination chemotherapy in vivo also significantly inhibited tumor growth compared to single use of each drug. Flow cytometry showed vandetanib increased the proportion in the $G_{1}$ phase, and in MKN74, combination therapy increased the early $S$ phase and caused bimodal peaks in the $G_{1}$ phase. The level of expression of cyclin D1 was clearly strong in MKN7 and MKN74 in the
\end{abstract}

This article is freely accessible online.

Correspondence to: Shinji Osada, MD, Department of Multidisciplinary Therapy for Hepato-Biliary- Pancreatic Cancer, Gifu University Graduate School of Medicine, 1-1 Yanagido, Gifu, 501-1194, Japan. Tel: +81 582306233, Fax: +81 582301074, e-mail: sting@gifu-u.ac.jp

Key Words: Gastric cancer, vandetanib, 5-FU, epidermal growth factor receptor (EGFR), cyclin D1. natural state, and the expression of cyclin D1, E2 promoter binding factor 1 and thymidylate synthase (TYMS) was inhibited by vandetanib, but not in MKN1 cells. The synergistic effect disappeared in MKN7 and MKN74 cells in vitro when cyclin DI was knocked-down by siRNA. Conclusion: The synergistic effect of vandetanib with 5-FU is related to vandetanib-induced reduction of TYMS via down-regulation of cyclin D1. Hyperexpression of cyclin D1 might be a biomarker of the synergistic effect.

Gastric cancer is one of the most common malignant diseases worldwide, especially in the Asian countries (1). Although the expansion of multidisciplinary care, including advances in chemotherapeutic agents and surgical techniques, has progressed, gastric cancer is still a lifethreating malignancy as the second leading cause of cancer mortality (2). In patients with stages II (excluding T1 disease) or III (moderately advanced) gastric cancer, the recurrence rate is extremely high, at $41.7 \%$ after surgery alone, even with curative resection (3). Thus, chemotherapy is expected to improve the prognosis for advanced or recurrent gastric cancer. Among anticancer agents, 5fluorouracil (5-FU) has been widely accepted for the treatment of gastric cancer and clinically represents the key drug. Indeed, current clinical trials have shown 5-FU to have a significant effect after surgery not only with single use (3, 4 ), but also in combination with cisplatin or docetaxel (5-8). However, in patients with unresectable or recurrent gastric cancer, the median survival time and 2-year survival rates are estimated to be 12.5-13.0 months and 22.9-23.6\% $(5,6)$. In order to exert a stronger effect of chemotherapeutic agents, the drug-delivery system needs to be considered or metabolic factors need to be changed (9). The action of 5FU depends on the presence of cellular thymidylate synthase (TYMS), which is one of the metabolic enzymes for 5-FU, and its growth-inhibitory effect is well-known to be affected 
by a decrease in TYMS (10). Thus, the development of a new therapeutic strategy with 5-FU to reduce TYMS expression would be of interest. Indeed, pre-clinical reports showed the down-regulation of TYMS to lead to the enhancement of the effect of 5-FU $(11,12)$.

Recent development has focused on molecular-targeting agents, including those for cell-surface receptors and intracellular signaling pathway-related proteins (13). Of them, in chemotherapy for gastric cancer, antagonizing agents for the receptors of epidermal growth factor (EGFR) or vascular endothelial growth factor (VEGFR) were revealed to play critical roles. In clinical trials, monoclonal antibody against VEGFR prolonged median survival time from 3.8 months to 5.2 months in patients with advanced gastric cancer (14). High expression of EGFR was also correlated with poor patient prognosis of gastric cancer (15, 16). Vandetanib (Caprelsa; Zactima; ZD6474) is a novel small-molecule tyrosine kinase inhibitor with inhibitory activity against VEGFR and EGFR $(17,18)$. In phase II and III trials for advanced non-small cell lung cancer, vandetanib showed promising activity not only as a monotherapy agent $(19,20)$, but also in combination with certain other chemotherapeutic agents (21-23). In fact, a recent report demonstrated that some inhibitors of EGFR reduces the expression of TYMS, resulting in enhancement of the efficacy of 5-FU in lung cancer cells (24).

The aim of the present study was to investigate the combination effect of vandetanib with 5-FU on gastric cancer cells and to elucidate the biochemical mechanism and biomarker of the synergistic interaction. By focusing on the metabolism of 5-FU, a novel treatment for gastric cancer with a molecular targeting agent might be developed.

\section{Materials and Methods}

Agents and cell culture. Vandetanib was kindly provided by AstraZeneca (Macclesfield, UK), and 5-FU was purchased from Kyowa Hakko (Tokyo, Japan).

MKN45 and TMK1 as poorly differentiated human gastric adenocarcinoma cell lines, MKN1 as an adenosquamous carcinoma cell line, and MKN7 and MKN74 as well-differentiated adenocarcinoma were selected. All of these gastric cancer cell lines were cultured in RPMI-1640 medium (Wako, Osaka, Japan) supplemented with 10\% fetal bovine serum, $1 \%$ penicillin-streptomycin-amphotericin solution, $1 \mathrm{mM}$ HEPES buffer, and $1 \mathrm{mM}$ sodium pyruvate solution (all from Sigma-Aldrich, St. Louis, MO, USA) in a humidified atmosphere of $95 \%$ air and $5 \% \mathrm{CO}_{2}$ at $37^{\circ} \mathrm{C}$.

Evaluation of cell viability. Cell growth was assessed with a standard 3-(4,5-dimethyl-2-tetrazolyl)-2,5-diphenyl- $2 \mathrm{H}$ tetrazolium bromide (MTT) assay, which detects the dehydrogenase activity in viable cells, as described previously $(25,26)$. A total of $5 \times 10^{3}$ cells were seeded in each well of 96-well culture plates. After $24 \mathrm{~h}$, the cells were treated with different concentrations of the study drugs alone and in combination. After another $72 \mathrm{~h}$, the culture medium was removed, and $100 \mu \mathrm{l}$ of a $0.5 \mathrm{mg} / \mathrm{ml}$ solution of MTT (Sigma-
Aldrich) was added to each well. The plates were then incubated for $4 \mathrm{~h}$ at $37^{\circ} \mathrm{C}$. The MTT solution was then removed and replaced with $100 \mu \mathrm{l}$ of dimethyl sulfoxide (Wako) per well, and the absorbance at $540 \mathrm{~nm}$ was measured using an Envision 2104 Multilabel Reader (Perkin Elmer, Waltham, MA, USA).

The combination index (CI) at the 50\% inhibitory concentration $\left(\mathrm{IC}_{50}\right)$ was calculated by the formula $\mathrm{CI}=A / A x+B / B x$, where A was the $\mathrm{IC}_{50}$ for drug $\mathrm{A}$ in combination, $A x$ was the $\mathrm{IC}_{50}$ for drug $\mathrm{A}$ alone, $B$ was the $\mathrm{IC}_{50}$ for drug $\mathrm{B}$ in combination, and $B x$ was the $\mathrm{IC}_{50}$ for drug $\mathrm{B}$ alone, based on the Loewe additivity model (27). CI values of $<1,1$, and $>1$ indicate synergistic, additive, and antagonistic effects, respectively.

Western blot analysis and antibodies used. Treated cells were harvested and lysed in CelLytic ${ }^{\mathrm{TM}} \mathrm{M}$ (Sigma-Aldrich) for $30 \mathrm{~min}$ on ice. The protein concentration of the lysates was measured using a DC Protein Assay Kit (Bio-Rad, Hercules, CA, USA). The cell lysates were boiled in Sample Buffer Solution (Wako), then total cell protein extracts $(20 \mu \mathrm{g} / \mathrm{lane})$ were separated by sodium dodecyl sulfate-polyacrylamide gel electrophoresis using SuperSep ${ }^{\mathrm{TM}}$ (Wako), and they were electrophoretically transferred onto polyvinyl difluoride (PVDF) membranes, as described previously $(25,26)$. The membranes were blocked with PVDF blocking reagent (TOYOBO, Osaka, Japan) for $1 \mathrm{~h}$. The membranes were then incubated with primary antibodies against $\beta$-actin, EGFR, phosphoEGFR (Tyr $\left.{ }^{1068}\right)$, extracellular signal-regulated kinase (ERK), phosphor-ERK ( $\mathrm{Thr}^{202} / \mathrm{Tyr}^{204}$ ), AKT, phospho-AKT (Ser ${ }^{473}$ ), cyclin B1, cyclin D1, (1:5,000; Cell Signaling Technology, Danvers, MA, USA); TYMS (1:2,500; Millipore, Darmstadt, Germany); and E2 promoter binding factor 1 (E2F1) (1:2500; Abcam, Cambridge, UK) overnight at $4{ }^{\circ} \mathrm{C}$. The primary antibodies were diluted with Can Get Signal Solution 1 (TOYOBO). The membranes were then washed with Dako Washing Buffer (Dako, Glostrup, Denmark) and incubated with the appropriate secondary antibodies $(1: 25,000$; Millipore). Secondary antibodies were diluted with Can Get Signal Solution 2 (TOYOBO). The immunoreactive proteins were visualized by chemiluminescence using ImmunoStar LD reagents (Wako), and images were captured by an LAS-4000 system (FUJIFILM, Tokyo, Japan).

Cell-cycle distribution. In order to study the effect of combination treatment of vandetanib and 5-FU, cells were treated with vandetanib with/without 5-FU for 12-96 h after seeding and cultured for $24 \mathrm{~h}$ in $100-\mathrm{mm}$ tissue culture dishes. After treatment, both attached and floating cells were collected and washed in phosphatebuffered saline (PBS), incubated in $70 \%$ ethanol, and kept at $-20^{\circ} \mathrm{C}$ overnight for fixation. Ethanol-fixed cells were centrifuged $(3,500$ $\mathrm{rpm}, 2,000 \times \mathrm{g}, 15 \mathrm{~min}$ ), re-suspended in PBS containing $200 \mu \mathrm{g} / \mathrm{ml}$ RNase A (Sigma) at $37^{\circ} \mathrm{C}$ for $30 \mathrm{~min}$, and stained with $20 \mu \mathrm{g} / \mathrm{ml}$ of propidium iodide (Wako) for $30 \mathrm{~min}$ in the dark. Apoptotic cells were determined by their hypochromic sub-diploid staining profiles. The distribution of cells in the different cell-cycle phases was analyzed from the DNA histogram using FACSCalibur (Becton Dickinson Immunocytometry Systems, San Jose, CA, USA). The data were analyzed using Cell Quest software (Becton Dickinson).

Transfection and small interfering RNA (siRNA) experiments for cyclin D1. Three siRNA duplexes were designed and synthesized for silencing cyclin D1. The duplexes were termed cyclin D1-1 (sense: 5'-UCC UGU GCU GCG AAG UGG AAA CCA U-3'; 
antisense: 5' - AUG GUU UCC ACU UCG CAG CAC AGG A 3'); cyclinD1-2 (sense: 5'-GGA GAA CAA ACA GAU CAU CCG CAA A-3'; antisense: 5'-UUU GCG GAU CUG UUU GUU CUC C-3'); and cyclin D1-3 (sense: 5'-GCG CCC UCG GUG UCC UAC UUC AAA U-3'; antisense: 5'-AUU UGA AGU AGG ACA CCG AGG GCG C-3'). The siRNA oligonucleotides (Stealth RNAi) and the negative control oligonucleotides (Stealth RNAi siRNA Negative Control) for cyclin D1 were purchased from Invitrogen (Carlsbad, CA, USA). MKN74 cells were cultured in medium without antibiotics for $24 \mathrm{~h}$ before transfection at 50-70\% confluence. The cells were transfected with a siRNA oligonucleotide using Lipofectamine RNAiMAX (Invitrogen) in a final siRNA concentration of $30 \mathrm{nmol} / 1$ in serum-free Opti-MEM (Invitrogen). After $48 \mathrm{~h}$, the total proteins were extracted, and the expression levels of the cyclin D1 protein were analyzed by western blotting.

Animals housing and in vivo experiments. Female 6-week-old nude mice (BALB/c nu/nu) were purchased from SRL (Hamamatsu, Japan) and housed in the animal facilities of the Division of Animal Experiment, Life Science Research Center, Gifu University with free access to water and food. Mice were acclimatized at the animal facilities for 1 week before receiving injections of cancer cells. Mice received a s.c. injection into their flanks of $5 \times 10^{6} \mathrm{MKN} 74$ cells that had been resuspended in $100 \mu \mathrm{l}$ of PBS. After 10 days, when established tumors of approximately $100 \mathrm{~mm}^{3}$ in volume were detected, mice were randomly allocated to four groups (10 mice per group) to be treated with (i) vehicle: $200 \mu 1$ sterile normal saline i.p. and $200 \mu \mathrm{l}$ distilled water with $1 \%$ Tween 80 p.o.; (ii) $15 \mathrm{mg} / \mathrm{kg} / \mathrm{day}$ 5-FU in $200 \mu \mathrm{l}$ sterile saline i.p. and vehicle control p.o.; (iii) $25 \mathrm{mg} / \mathrm{kg} /$ day vandetanib in $200 \mu \mathrm{l}$ distilled water with $1 \%$ Tween 80 p.o. and vehicle control i.p.; and (iv) $15 \mathrm{mg} / \mathrm{kg} / \mathrm{day} 5-\mathrm{FU}$ i.p. and $25 \mathrm{mg} / \mathrm{kg} / \mathrm{day}$ vandetanib p.o. on days $1-5$ of each week for 4 weeks, respectively. Tumor volume was measured using the formula $\pi / 6 \times$ largest diameter $\times$ (smallest diameter $)^{2}$. In order to evaluate the antitumor effects of 5-FU and vandetanib, tumor sizes were measured every 3 days. The mice were subsequently killed at day 29 of initial treatment, and their tumors were excised and the tumor weight was evaluated. Animal experiments in this study were performed in compliance with the guidelines of the Institute for Laboratory Animal Research, Gifu University Graduate School of Medicine, and the UKCCCR Guidelines for the Welfare of Animals in Experimental Neoplasia.

Statistical analysis. The data were examined using the Student $t$ test, $\chi^{2}$ test, and ANOVA or Kruskal-Wallis test (with appropriate post hoc analysis for multiple comparisons) to determine statistical significance. Tumor volumes from the control group were compared with those from the three treatment groups using the Student $t$-test, and to evaluate the synergistic effect of the drugs, the CI was calculated by using the Loewe additivity model (27). For all comparisons, a $p$-value of less than 0.05 was regarded as statistically significant.

\section{Results}

Synergic effect of 5-FU with vandetanib on gastric cancer cell growth. Vandetanib inhibited the growth of the gastric cancer cell lines and their $\mathrm{IC}_{50}$ s were calculated as $3.5 \pm 1.2 \mu \mathrm{M}$ against MKN1, 5.1 $\pm 1.2 \mu \mathrm{M}$ against MKN7, 4.1 $\pm 0.2 \mu \mathrm{M}$ against MKN45, 3.8 $\pm 0.1 \mu \mathrm{M}$ against MKN74, and 19.1 $\pm 3.6 \mu \mathrm{M}$ against TMK1. The single use of 5-FU and its combination with vandetanib also showed a growth-inhibitory effect on these cell lines (Figure 1). In MKN74 cells under combined use of vandetanib at doses of $0.25 \mu \mathrm{M}, 1 \mu \mathrm{M}$, and $2.5 \mu \mathrm{M}$, the $\mathrm{IC}_{50} \mathrm{~s}$ for $5-\mathrm{FU}$ were $29.0 \pm 15.7 \mu \mathrm{M}, 6.2 \pm 3.6 \mu \mathrm{M}$, and $0.24 \pm 0.22 \mu \mathrm{M}$, respectively. The CIs were calculated as $0.35 \pm 0.14,0.32 \pm 0.03$, and $0.65 \pm 0.02$, respectively. In MKN7 cells, under $0.25 \mu \mathrm{M}, 1 \mu \mathrm{M}$, and $2.5 \mu \mathrm{M}$ doses of vandetanib, the $\mathrm{IC}_{50} \mathrm{~s}$ for 5-FU were $64.5 \mu \mathrm{M}, 17.4 \mu \mathrm{M}$, and $3.03 \mu \mathrm{M}$, and the CIs were $0.559,0.394$, and 0.677 , respectively, indicating the synergistic effect of vandetanib with 5-FU in MKN74 and MKN7 cells, but simply an additional effect in the other cell lines such as MKN1.

For the in vivo experiments, the synergistic effect of vandetanib with 5-FU was examined in a mouse model with the MKN74 cell line (Figure 2). The single use of vandetanib significantly reduced tumor volume compared to the control on day $9(p=0.0278)$, and this effect was maintained continuously to day 28 ( $p=0.0002)$. In combination with vandetanib, the effect of 5-FU in inhibiting tumor volume was clearly increased compared to the single use of 5-FU from day 9 ( $p=0.0134)$, with this effect maintained to day $28(p=0.0041)$, and also compared to the control from day $6(p=0.0085)$, with this effect maintained to day $28(p<0.0001)$, respectively. The tumor weight on day 28 was also significantly reduced by the combination of vandetanib and 5-FU compared to the single use of each drug ( $p=0.0001$ and 0.0097 , respectively).

Effect on cellular signaling. Vandetanib and 5-FU-mediated signal transduction was examined to compare cell lines showing a synergistic effect (MKN74) or an additional action (MKN1) (Figure 3). The activity of EGFR was completely inhibited by vandetanib in a dose-dependent manner, and its downstream phosphorylation of ERK was also blocked in both cell lines.

Flow cytometric analysis showed that vandetanib increased the proportion of cells in the $G_{1}$ phase while reducing the $S$-phase proportion in a time-dependent manner in both cell lines. In contrast, the S-phase population was increased by single use of 5-FU in both cell lines in a timedependent manner, and a similar change was detected in MKN1 cells by combination treatment with vandetanib. In MKN74 cells, however, the combination increased the early $S$-phase population and caused bimodal peaks in the $\mathrm{G}_{1^{-}}$ phase population. As shown in Figure 4, the expression of cyclin D1, E2F1 and TYMS was inhibited by vandetanib in a dose-dependent manner in MKN74 cells but not in MKN1. Similar results to those for MKN74 cells were detected in MKN7 cells (data not shown).

Significance of the synergistic effect of cyclin D1. The expression levels of cellular signaling-related proteins were compared between the gastric cancer cell lines (Figure 5). 

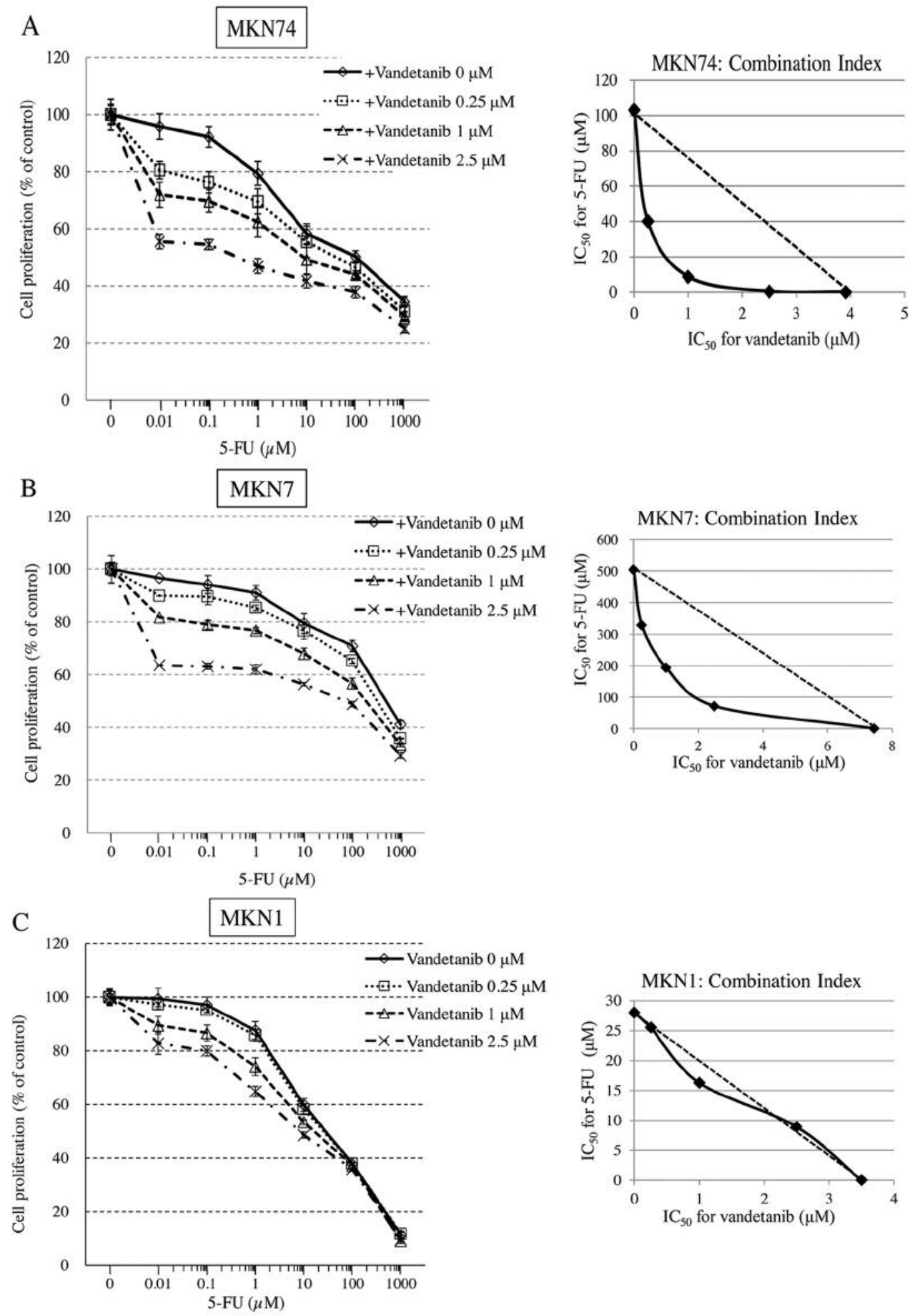

Figure 1. Effect of the combination of 5-fluorouracil (5-FU) and vandetanib on gastric cancer cell growth in vitro. In order to verify that there were synergistic effects of 5-FU and vandetanib against gastric cancer cells, we performed a 3-(4,5-dimethyl-2-tetrazolyl)-2,5-diphenyl-2H tetrazolium bromide assay using these drugs in MKN74 (A), MKN7 (B), and MKN1 (C) cells. Cell survival was analyzed after incubation for $72 \mathrm{~h}$ from the administration of the drugs. The synergistic effect of the drugs was evaluated using the combination index (CI) calculated by the Loewe additivity model (27). CI values of $\langle 1,1$, and $>1$ indicate synergistic, additive, and antagonistic effects, respectively. The dotted-line of the CI graph indicates the line of CI equal to 1 . All values are representative of at least three independent experiments. 
A
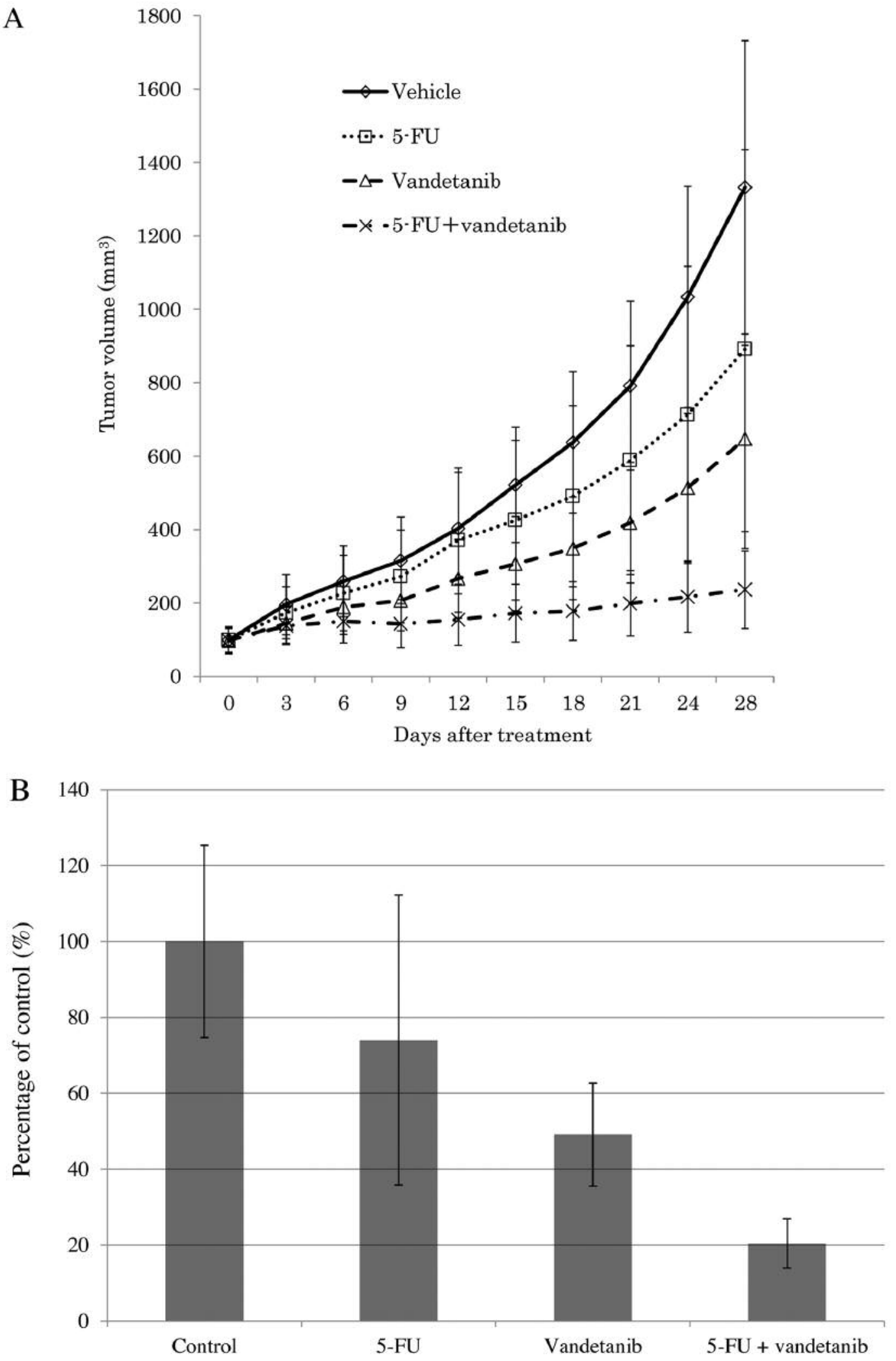

Figure 2. In vivo effects of vandetanib with/without 5-fluorouracil (5-FU) on tumor growth. The mice (MKN74) in vivo experiment was performed as described in the Material and Methods section. Tumor growth curves on each day were plotted (A). The mice were subsequently killed on day 29 of initial treatment, and tumor weight was evaluated $(B)$. Data are the mean $\pm S D$. 

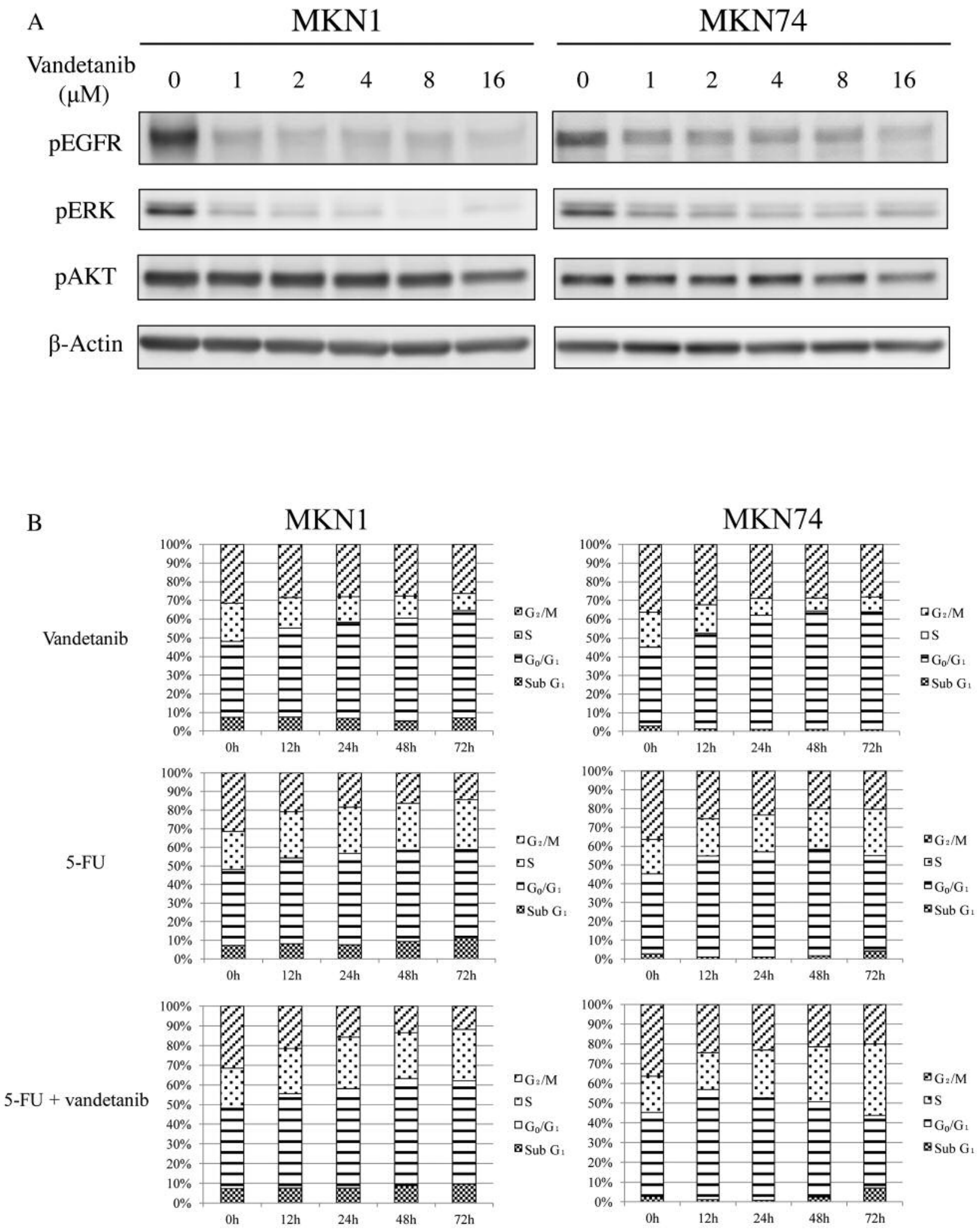

Figure 3. Continued 


\section{C $\quad$ MKN74}
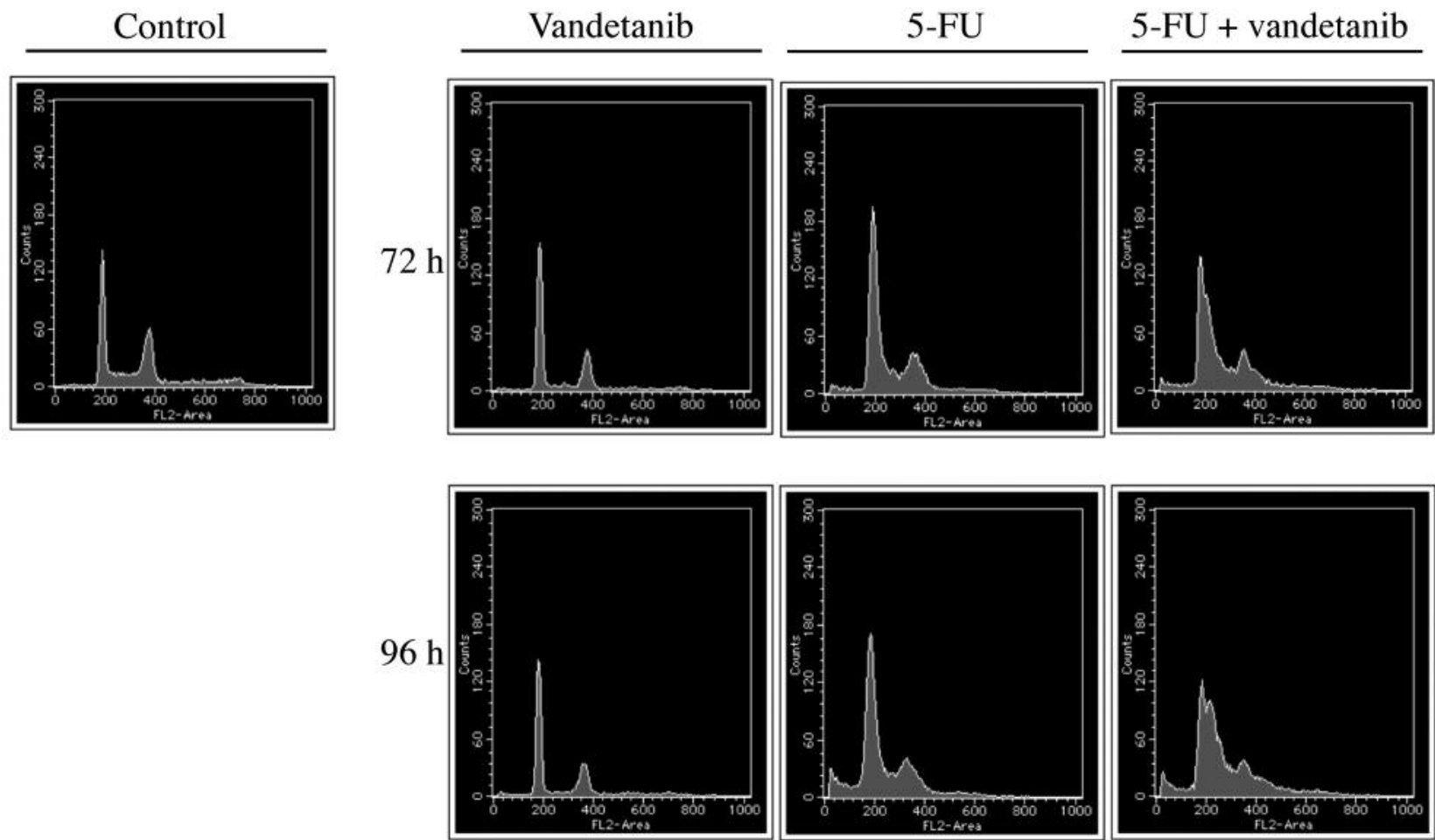

Figure 3. Comparison of the effects of vandetanib with/without 5-fluorouracil (5-FU) on signal transduction and the cell cycle distribution. A: Effects on the phosphorylation status of epidermal growth factor receptor (EGFR) and its downstream signaling in MKN1 and MKN74 cells treated with vandetanib at the indicated concentrations for 30 min as analyzed by western blotting. $\beta$-Actin was used as a loading control. B: Cell-cycle analysis of MKN1 and MKN74 cells treated with vandetanib with/without 5-FU. Cells were treated with these drugs at the indicated times after seeding and culture for $24 \mathrm{~h}$. The DNA contents of the cells were analyzed by flow cytometry. The cell-cycle distributions are shown. C: The histograms of no treatment at $O \mathrm{~h}$ as the control and those for treatment with vandetanib $(4 \mu \mathrm{M})$ with/without 5-FU (150 $\mu \mathrm{M})$ for $72 \mathrm{~h}$ and $96 \mathrm{~h}$ in MKN74 cells are shown.

The expression of EGFR was strong in MKN1, MKN7, and MKN74 cells but was slightly weak in MKN45 and TMK1 cells. Phosphorylated EGFR was clearly detected in MKN1 and weakly detected in MKN7 cells, but almost none was detected in the other cell lines. In contrast, the expression level of cyclin D1 was clearly strong in MKN7 and MKN74 cells but not in the other cell lines.

In order to demonstrate the possibility of a significant relation of cyclin D1 with the synergistic action of 5-FU and vandetanib, the effect of a cellular RNA blockage technique, siRNA, was studied on MKN7 and MKN74 cells (Figure 6). In MKN74 cells with blocked expression of cyclin D1, at doses of $0.25 \mu \mathrm{M}, 1 \mu \mathrm{M}$, and $2.5 \mu \mathrm{M}$ of vandetanib, the CIs of the combination with 5 -FU were calculated as 0.978 , 0.888 , and 1.007 , respectively. In the cells with siRNA2, the CIs were $0.939,0.88$, and 0.714 , and with siRNA3, they were $0.993,1.075$, and 0.898 , respectively, indicating that the blockage of highly expressed cyclin D1 diminished the synergistic action. In another targeted cell line, MKN7, with siRNA1, the CIs were calculated as $0.969,0.852$, and 0.800 ; with siRNA2 as $0.986,0.910$, and 0.854 ; and with siRNA3 as $0.988,1.081$, and 0.856 .

\section{Discussion}

Recent developments in cancer chemotherapy have focused on the combination of standard therapeutic drugs with molecular targeting agents $(28,29)$. In fact, for the treatment of gastric cancer, various clinical phase III trials targeting the receptor of EGF or VEGF have been conducted, but expected outcomes have not yet been reported $(30,31)$. Despite these trials recruiting over 1,450 patients, negative and inferior results compared to the control arm with chemotherapy alone were reported because patient selection 


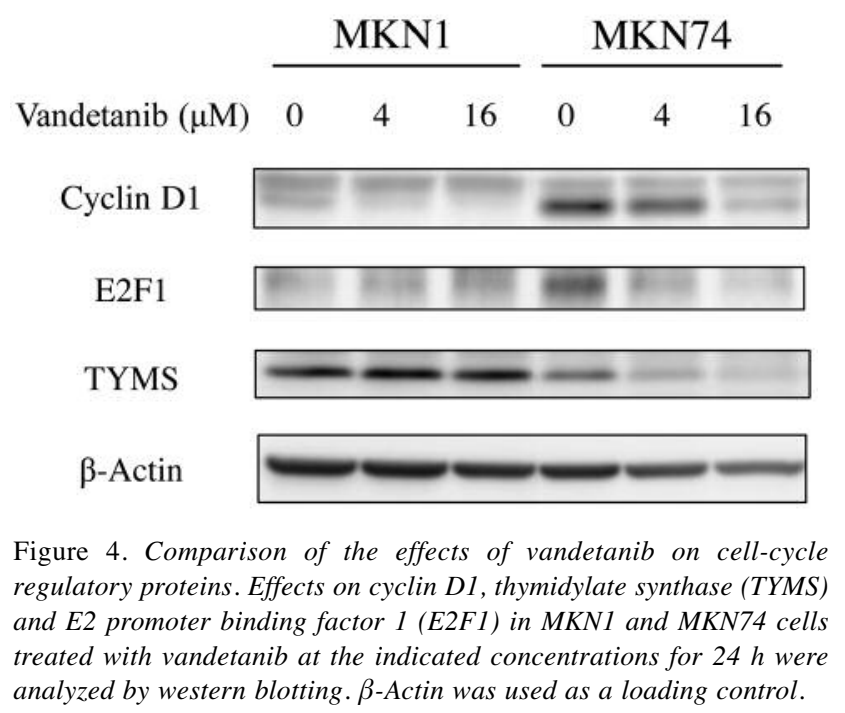

was not optimized. In order to improve the new targeting therapy, several points remain in terms of the biological knowledge of gastric cancer. The selection of patients based on the identification of specific predictive biomarkers appears to be a very crucial point (29). As well, an understanding of the different molecular alterations that play a pivotal role in each case will undoubtedly be a main factor in the development of targeted therapy. A biological approach to understanding the mechanisms involved in the synergistic action of vandetanib with 5-FU is supported by the present study.

The D-type cyclins associate with cyclin-dependent kinase 4 and 6 and play an important role early in the $G_{1}$ phase of the cell cycle. These complexes phosphorylate retinoblastoma protein and inactive its ability to act as a transcriptional repressor in a complex with E2F1 (32). Because the $E 2 F 1$ gene is a key regulator for $\mathrm{G}_{1} / \mathrm{S}$ phase transition (33), down-regulation of cyclin D1 by vandetanib (Figure 4) is thought to lead to the shutdown of E2Fmediated transcriptional activity (34). In fact the E2F family is considered one of the main regulators of cell growth and proliferation (35). The overexpression of E2F1 is a risk factor for malignant tumors (36), and it might be related to suppression of the progression or induction of apoptosis in several types of cancer (37), indicating that the $E 2 F 1$ gene has a dual effect in promoting cell proliferation and apoptosis. A recent study demonstrated that E2F1 overexpression had a significant influence on cell-cycle progression and proliferation of gastric cancer cells (38), despite the fact that the underlying molecular mechanisms remain unclear. This evidence might support the present study result of the reduction of E2F1 by vandetanib. Because E2F1 is an upstream transcriptional regulator of TYMS, its
A

\section{MKN1 MKN7 MKN45 MKN74 TMK1}

EGFR

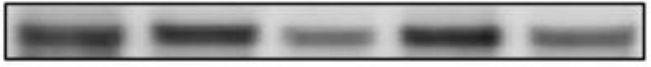

pEGFR

$\beta$-Actin

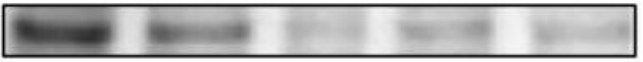

B

MKN1 MKN7 MKN45 MKN74 TMK1

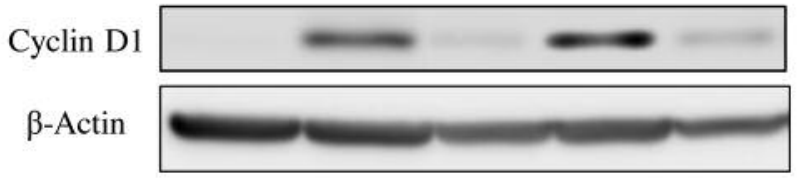

Figure 5. Expression levels of cellular signaling-related proteins. Expression of epidermal growth factor receptor (EGFR) and its phosphorylated form in human gastric cancer cell lines were analyzed by western blotting $(A)$. The levels of cyclin D1 expression were also evaluated by western blotting (B). $\beta$-Actin was used as a loading control.

reduction decreases the level of TYMS directly or through the down-regulation of cyclin D1, as described in current reports $(34,39,40)$. In addition, the inhibition of cellular proliferative signaling factors ERK or AKT are also related to the decreasing action of cyclin D1 in gastric cancer cell lines $(41,42)$. In the cell lines used here (MKN7 and MKN74) with high expression of cyclin D1, the combination of vandetanib with 5-FU increased the early $S$ phase population and caused bimodal peaks in the $G_{1}$ phase in the flow cytometry experiment, suggesting that the reduction of TYMS enhanced the effect of 5-FU (Figure 3). The importance of cyclin D1 to this synergistic effect was also demonstrated on the mRNA level (Figure 6).

Although the therapeutic strategies are planned with the expectation of favorable outcomes, this is not always the case. Efforts to provide greater treatment benefit to patients with cancer might be associated with an understanding of the mechanism of action or factors causing resistance (43). The protein levels of TYMS is well known to significantly correlate with the response to 5-FU-based therapy in several cancer cell lines $(13,44)$. In fact, the metabolic enzymes, such as TYMS for 5-FU, and the signaling pathways, such as B-cell lymphoma 2 (BCL2) for taxane (45), have been considered as chemo-predictive markers. New knowledge of these markers is being evaluated to determine the selection of individual patients for personalized therapy. In fact, patients with gastric cancer who show a poor response to 


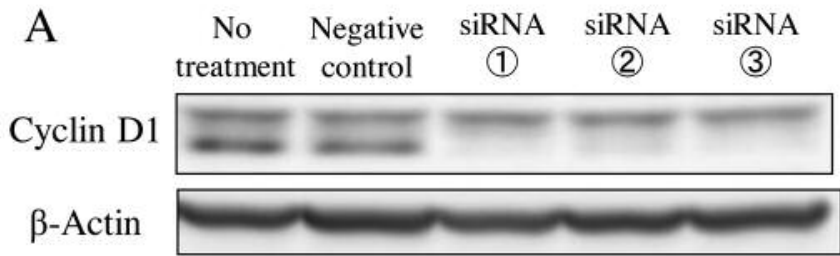

\section{B MKN74}

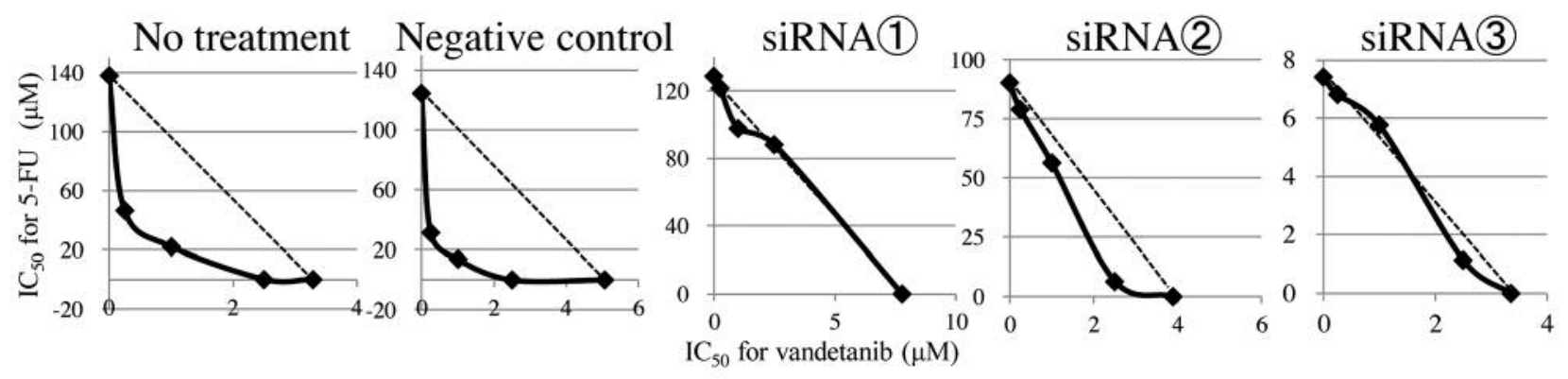

\section{MKN7}

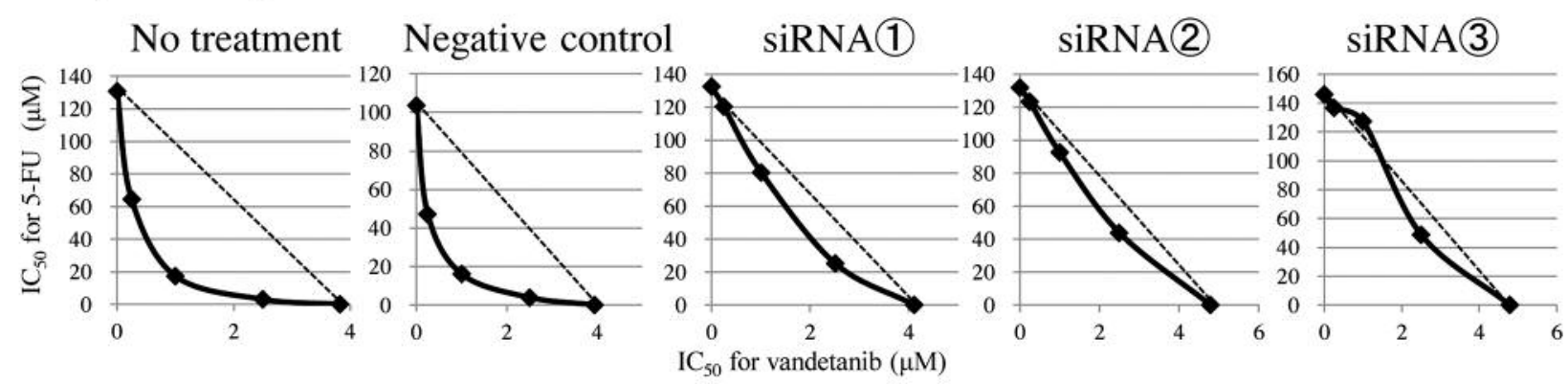

Figure 6. Down-regulation of cyclin D1 after transfection of cells with a small interfering RNA (siRNA) oligonucleotide against cyclin D1. Three types of siRNA oligonucleotide against cyclin D1 were transfected into MKN74 and MKN7 cells, and the expression of cyclin D1 in MKN74 cells was evaluated (A). In MKN74 cells treated with $0.25 \mu \mathrm{M}, 1 \mu \mathrm{M}$, and $2.5 \mu \mathrm{M}$ of vandetanib with 5-FU, the combination index was nearly 1 in the cells after transfection of any of the three types of siRNA against cyclin D1, indicating that the synergistic effect had disappeared (B). Similar results were found in MKN7 cells (C). Control oligonucleotide as a negative control had no effect on the synergy of vandetanib and 5-FU in both cell lines.

first-line chemotherapy are considered to have a dismal prognosis (46). Therefore, reliable biomarkers that can predict the response to chemotherapy are urgently needed to improve the efficiency of chemotherapy for patients with advanced gastric cancer. In addition, recent studies have suggested that the response to first-line chemotherapy is strongly correlated with the disease-free survival term and overall survival in patients with advanced gastric cancer (47). Thus, the outcome in patients with advanced gastric cancer is markedly dependent on the response to first-line chemotherapy; therefore, it is very important to identify biomarkers that can be used to predict the responses of such patients to anticancer agents. In the present study, as one of the reliable indications, cyclin D1 was shown to play a significant role not only in mediating the synergistic effect of the combination of vandetanib with 5-FU but also to predict its outcome. The overexpression of cyclin D1 is well known to promote cell growth and carcinogenesis because of its capacity as an oncogene $(48,49)$. Actually, current studies have also highlighted the significance of cyclin D1 to promote local cancer progression and to lead to distant metastases $(50,51)$. The expression rate of cyclin $\mathrm{D} 1$ protein was found to be extremely high, $47.4 \%$ and $50.0 \%$, in the primary region and in metastatic lymph nodes, respectively, 
in advanced gastric cancer (52). Although the value of cyclin D1 expression as it relates to chemotherapy is not yet controversial in gastric cancer, the patient prognosis is reported to have a tendency to worsen (53). In contrast, a higher level of cyclin D1 was shown to correlate with better patient prognosis in colorectal cancer, even if the relation of the anticancer drug effect was not described (54). It is possible in colorectal cancer that the expression of cyclin D1 is not an indicator of the chemosensitivity to 5-FU (55), but the synergistic effect of cyclin D1 with molecular-targeting drugs has not yet been demonstrated. However, chemosensitivity to 5-FU was predicted to be significantly better for patients with low expression of cyclin D1 in squamous cell carcinoma (56).

To the best of our knowledge, this is the first report of the enhancement of the antitumor activity of vandetanib with 5FU, especially for gastric cancer cells with high expression of cyclin D1. The effect of a novel chemotherapy regimen established with the combination of vandetanib and 5-FU might be predicted based on the level of cyclin D1 expression. A clinical trial to support the findings of the present study is expected in the near future.

\section{Conclusion}

The synergistic effect of vandetanib in combination with 5FU was demonstrated through the reduction of TYMS by E2F1 and cyclin D1 in gastric cancer cell lines. The significance of cyclin D1 expression may allow its use as a biomarker to predict the effect of combination therapy with vandetanib and 5-FU.

\section{References}

1 Shen L, Shan YS, Hu HM, Price TJ, Sirohi B, Yeh KH, Yang YH, Sano T, Yang HK, Zhang X, Park SR, Fujii M, Kang YK and Chen LT: Management of gastric cancer in Asia: resourcestratified guidelines. Lancet Oncol 14: e535-547, 2013.

2 Jemal A, Bray F, Center MM, Ferlay J, Ward E and Forman D: Global cancer statistics. CA-Cancer J Clin 61: 69-90, 2011.

3 Sasako M, Sakuramoto S, Katai H, Kinoshita T, Furukawa H, Yamaguchi T, Nashimoto A, Fujii M, Nakajima T and Ohashi Y: Five-year outcomes of a randomized phase III trial comparing adjuvant chemotherapy with S-1 versus surgery alone in stage II or III gastric cancer. J Clin Oncol 29: 4387-4393, 2011.

4 Sakuramoto S, Sasako M, Yamaguchi T, Kinoshita T, Fujii M, Nashimoto A, Furukawa H, Nakajima T, Ohashi Y, Imamura H, Higashino M, Yamamura Y, Kurita A and Arai K: Adjuvant chemotherapy for gastric cancer with S-1, an oral fluoropyrimidine. New Engl J Med 357: 1810-1820, 2007.

5 Koizumi W, Narahara H, Hara T, Takagane A, Akiya T, Takagi M, Miyashita K, Nishizaki T, Kobayashi O, Takiyama W, Toh Y, Nagaie T, Takagi S, Yamamura Y, Yanaoka K, Orita $\mathrm{H}$ and Takeuchi M: S-1 plus cisplatin versus S-1 alone for first-line treatment of advanced gastric cancer (SPIRITS trial): a phase III trial. Lancet Oncol 9: 215-221, 2008.
6 Koizumi W, Kim YH, Fujii M, Kim HK, Imamura H, Lee KH, Hara T, Chung HC, Satoh T, Cho JY, Hosaka H, Tsuji A, Takagane A, Inokuchi M, Tanabe K, Okuno T, Ogura M, Yoshida K, Takeuchi M, Nakajima T, Jaccro and Group KS: Addition of docetaxel to S-1 without platinum prolongs survival of patients with advanced gastric cancer: a randomized study (START). J Cancer Res Clin Oncol 140: 319-328, 2014.

7 Yoshida K, Ninomiya M, Takakura N, Hirabayashi N, Takiyama W, Sato Y, Todo S, Terashima M, Gotoh M, Sakamoto J and Nishiyama M: Phase II study of docetaxel and S-1 combination therapy for advanced or recurrent gastric cancer. Clin Cancer Res 12: 3402-3407, 2006.

8 Tanabe K, Suzuki T, Tokumoto N, Yamamoto H, Yoshida K and Ohdan H: Combination therapy with docetaxel and S-1 as a firstline treatment in patients with advanced or recurrent gastric cancer: a retrospective analysis. World J Surg Oncol 8: 40, 2010.

9 Osada S and Yoshida K: Application of biological study for met expression to cancer therapy. Anticancer Agents Med Chem 10: 58-63, 2010.

10 Watanabe M, Sowa Y, Yogosawa M and Sakai T: Novel MEK inhibitor trametinib and other retinoblastoma gene (RB)reactivating agents enhance efficacy of 5-fluorouracil on human colon cancer cells. Cancer Sci 104: 687-693, 2013.

11 Lee JH, Park JH, Jung Y, Kim JH, Jong HS, Kim TY and Bang YJ: Histone deacetylase inhibitor enhances 5-fluorouracil cytotoxicity by down-regulating thymidylate synthase in human cancer cells. Mol Cancer Ther 5: 3085-3095, 2006.

12 Wada Y, Yoshida K, Suzuki T, Mizuiri H, Konishi K, Ukon K, Tanabe K, Sakata Y and Fukushima M: Synergistic effects of docetaxel and S-1 by modulating the expression of metabolic enzymes of 5-fluorouracil in human gastric cancer cell lines. Int J Cancer 119: 783-791, 2006.

13 Lim SM, Lim JY and Cho JY: Targeted therapy in gastric cancer: Personalizing cancer treatment based on patient genome. World J Gastroenterol 20: 2042-2050, 2014.

14 Fuchs CS, Tomasek J, Yong CJ, Dumitru F, Passalacqua R, Goswami C, Safran H, dos Santos LV, Aprile G, Ferry DR, Melichar B, Tehfe M, Topuzov E, Zalcberg JR, Chau I, Campbell W, Sivanandan C, Pikiel J, Koshiji M, Hsu Y, Liepa AM, Gao L, Schwartz JD and Tabernero J: Ramucirumab monotherapy for previously treated advanced gastric or gastro-oesophageal junction adenocarcinoma (REGARD): an international, randomised, multicentre, placebo-controlled, phase 3 trial. Lancet 383: 31-39, 2014.

15 Terashima M, Kitada K, Ochiai A, Ichikawa W, Kurahashi I, Sakuramoto S, Katai H, Sano T, Imamura H and Sasako M: Impact of expression of human epidermal growth factor receptors EGFR and ERBB2 on survival in stage II/III gastric cancer. Clin Cancer Res 18: 5992-6000, 2012.

16 Chen C, Yang JM, Hu TT, Xu TJ, Yan G, Hu SL, Wei W and Xu WP: Prognostic role of human epidermal growth factor receptor in gastric cancer: a systematic review and meta-analysis. Arch Med Res 44: 380-389, 2013.

17 Gule MK, Chen Y, Sano D, Frederick MJ, Zhou G, Zhao M, Milas ZL, Galer CE, Henderson YC, Jasser SA, Schwartz DL, Bankson JA, Myers JN and Lai SY: Targeted therapy of VEGFR2 and EGFR significantly inhibits growth of anaplastic thyroid cancer in an orthotopic murine model. Clin Cancer Res 17: 2281-2291, 2011. 
18 Inoue $\mathrm{K}$, Torimura $\mathrm{T}$, Nakamura $\mathrm{T}$, Iwamoto $\mathrm{H}$, Masuda $\mathrm{H}$, Abe M, Hashimoto O, Koga $\mathrm{H}$, Ueno $\mathrm{T}$, Yano $\mathrm{H}$ and Sata $\mathrm{M}$ : Vandetanib, an inhibitor of VEGF receptor-2 and EGF receptor, suppresses tumor development and improves prognosis of liver cancer in mice. Clin Cancer Res 18: 3924-3933, 2012.

19 Natale RB, Bodkin D, Govindan R, Sleckman BG, Rizvi NA, Capo A, Germonpre P, Eberhardt WE, Stockman PK, Kennedy SJ and Ranson M: Vandetanib versus gefitinib in patients with advanced non-small-cell lung cancer: results from a two-part, double-blind, randomized phase ii study. J Clin Oncol 27: 25232529, 2009.

20 Natale RB, Thongprasert S, Greco FA, Thomas M, Tsai CM, Sunpaweravong P, Ferry D, Mulatero C, Whorf R, Thompson J, Barlesi F, Langmuir P, Gogov S, Rowbottom JA and Goss GD: Phase III trial of vandetanib compared with erlotinib in patients with previously treated advanced non-small-cell lung cancer. J Clin Oncol 29: 1059-1066, 2011.

21 Heymach JV, Johnson BE, Prager D, Csada E, Roubec J, Pesek M, Spasova I, Belani CP, Bodrogi I, Gadgeel S, Kennedy SJ, Hou J and Herbst RS: Randomized, placebo-controlled phase II study of vandetanib plus docetaxel in previously treated non small-cell lung cancer. J Clin Oncol 25: 4270-4277, 2007.

22 Herbst RS, Sun Y, Eberhardt WE, Germonpre P, Saijo N, Zhou C, Wang J, Li L, Kabbinavar F, Ichinose Y, Qin S, Zhang L, Biesma B, Heymach JV, Langmuir P, Kennedy SJ, Tada H and Johnson BE: Vandetanib plus docetaxel versus docetaxel as second-line treatment for patients with advanced non-small-cell lung cancer (ZODIAC): a double-blind, randomised, phase 3 trial. Lancet Oncol 11: 619-626, 2010.

23 de Boer RH, Arrieta O, Yang CH, Gottfried M, Chan V, Raats J, de Marinis F, Abratt RP, Wolf J, Blackhall FH, Langmuir P, Milenkova T, Read J and Vansteenkiste JF: Vandetanib plus pemetrexed for the second-line treatment of advanced non-smallcell lung cancer: a randomized, double-blind phase III trial. J Clin Oncol 29: 1067-1074, 2011.

24 Okabe T, Okamoto I, Tsukioka S, Uchida J, Iwasa T, Yoshida T, Hatashita E, Yamada Y, Satoh T, Tamura K, Fukuoka M and Nakagawa K: Synergistic antitumor effect of S-1 and the epidermal growth factor receptor inhibitor gefitinib in non-small cell lung cancer cell lines: role of gefitinib-induced down-regulation of thymidylate synthase. Mol Cancer Ther 7: 599-606, 2008.

25 Tanahashi T, Osada S, Yamada A, Kato J, Yawata K, Mori R, Imai H, Sasaki Y, Saito S, Tanaka Y, Nonaka K and Yoshida K: Extracellular signal-regulated kinase and Akt activation play a critical role in the process of hepatocyte growth factor-induced epithelial-mesenchymal transition. Int J Oncol 42: 556-564, 2013.

26 Mori R, Yoshida K, Tanahashi T, Yawata K, Kato J, Okumura N, Tsutani Y, Okada M, Oue N and Yasui W: Decreased FANCJ caused by $5 \mathrm{FU}$ contributes to the increased sensitivity to oxaliplatin in gastric cancer cells. Gastric Cancer 16: 345-354, 2013.

27 Tallarida RJ: Drug synergism: its detection and applications. J Pharmacol Exp Ther 298: 865-872, 2001.

28 Bang YJ, Van Cutsem E, Feyereislova A, Chung HC, Shen L, Sawaki A, Lordick F, Ohtsu A, Omuro Y, Satoh T, Aprile G, Kulikov E, Hill J, Lehle M, Ruschoff J and Kang YK: Trastuzumab in combination with chemotherapy versus chemotherapy alone for treatment of HER2-positive advanced gastric or gastro-oesophageal junction cancer (ToGA): a phase 3, open-label, randomised controlled trial. Lancet 376: 687-697, 2010.
29 De Vita F, Di Martino N, Fabozzi A, Laterza MM, Ventriglia J, Savastano B, Petrillo A, Gambardella V, Sforza V, Marano L, Auricchio A, Galizia G, Ciardiello F and Orditura M: Clinical management of advanced gastric cancer: The role of new molecular drugs. World J Gastroenterol: WJG 20: 14537-14558, 2014.

30 Waddell T, Chau I, Cunningham D, Gonzalez D, Okines AF, Okines C, Wotherspoon A, Saffery C, Middleton G, Wadsley J, Ferry D, Mansoor W, Crosby T, Coxon F, Smith D, Waters J, Iveson T, Falk S, Slater S, Peckitt $\mathrm{C}$ and Barbachano Y: Epirubicin, oxaliplatin and capecitabine with or without panitumumab for patients with previously untreated advanced oesophagogastric cancer (REAL3): a randomised, open-label phase 3 trial. Lancet Oncol 14: 481-489, 2013.

31 Lordick F, Kang YK, Chung HC, Salman P, Oh SC, Bodoky G, Kurteva G, Volovat C, Moiseyenko VM, Gorbunova V, Park JO, Sawaki A, Celik I, Gotte H, Melezinkova H and Moehler M: Capecitabine and cisplatin with or without cetuximab for patients with previously untreated advanced gastric cancer (EXPAND): a randomised, open-label phase 3 trial. Lancet Oncol 14: 490-499, 2013.

32 Pestell RG, Albanese C, Reutens AT, Segall JE, Lee RJ and Arnold A: The cyclins and cyclin-dependent kinase inhibitors in hormonal regulation of proliferation and differentiation. Endocr Rev 20: 501-534, 1999.

33 Hallstrom TC and Nevins JR: Balancing the decision of cell proliferation and cell fate. Cell Cycle 8: 532-535, 2009.

34 Kobayashi S, Shimamura T, Monti S, Steidl U, Hetherington CJ, Lowell AM, Golub T, Meyerson M, Tenen DG, Shapiro GI and Halmos B: Transcriptional profiling identifies cyclin D1 as a critical downstream effector of mutant epidermal growth factor receptor signaling. Cancer Res 66: 11389-11398, 2006.

35 DeGregori J and Johnson DG: Distinct and Overlapping Roles for E2F Family Members in Transcription, Proliferation and Apoptosis. Curr Mol Med 6: 739-748, 2006.

36 Molina-Privado I, Rodriguez-Martinez M, Rebollo P, MartinPerez D, Artiga MJ, Menarguez J, Flemington EK, Piris MA and Campanero MR: E2F1 expression is deregulated and plays an oncogenic role in sporadic Burkitt's lymphoma. Cancer Res 69: 4052-4058, 2009.

37 Liontos M, Niforou K, Velimezi G, Vougas K, Evangelou K, Apostolopoulou K, Vrtel R, Damalas A, Kontovazenitis P, Kotsinas A, Zoumpourlis V, Tsangaris GT, Kittas C, Ginsberg D, Halazonetis TD, Bartek $\mathbf{J}$ and Gorgoulis VG: Modulation of the E2F1-driven cancer cell fate by the DNA damage response machinery and potential novel E2F1 targets in osteosarcomas. Am J Pathol 175: 376-391, 2009.

38 Xie Y, Wang C, Li L, Ma Y, Yin Y and Xiao Q: Overexpression of E2F-1 inhibits progression of gastric cancer in vitro. Cell Biol Int 33: 640-649, 2009.

39 Suenaga M, Yamaguchi A, Soda H, Orihara K, Tokito Y, Sakaki Y, Umehara M, Terashi K, Kawamata N, Oka M, Kohno S and Tei C: Antiproliferative effects of gefitinib are associated with suppression of E2F-1 expression and telomerase activity. Anticancer Res 26: 3387-3391, 2006.

40 Giovannetti E, Zucali PA, Assaraf YG, Leon LG, Smid K, Alecci C, Giancola F, Destro A, Gianoncelli L, Lorenzi E, Roncalli M, Santoro A and Peters GJ: Preclinical emergence of vandetanib as a potent antitumour agent in mesothelioma: molecular mechanisms underlying its synergistic interaction with pemetrexed and carboplatin. Brit J Cancer 105: 1542-1553, 2011. 
41 Strecker TE, Shen Q, Zhang Y, Hill JL, Li Y, Wang C, Kim HT, Gilmer TM, Sexton KR, Hilsenbeck SG, Osborne CK and Brown PH: Effect of lapatinib on the development of estrogen receptor-negative mammary tumors in mice. J Natl Cancer I 101: 107-113, 2009.

42 Liu X, Guo WJ, Zhang XW, Cai X, Tian S and Li J: Cetuximab enhances the activities of irinotecan on gastric cancer cell lines through downregulating the EGFR pathway upregulated by irinotecan. Cancer Chemoth Pharm 68: 871-878, 2011.

43 Osada S, Tomita H, Tanaka Y, Tokuyama Y, Tanaka H, Sakashita $\mathrm{F}$ and Takahashi $\mathrm{T}$ : The utility of vitamin $\mathrm{K} 3$ (menadione) against pancreatic cancer. Anticancer Res 28: 45-50, 2008.

44 Jung YD, Mansfield PF, Akagi M, Takeda A, Liu W, Bucana CD, Hicklin DJ and Ellis LM: Effects of combination anti-vascular endothelial growth factor receptor and anti-epidermal growth factor receptor therapies on the growth of gastric cancer in a nude mouse model. Eur J Cancer 38: 1133-1140, 2002.

45 Murray S, Briasoulis E, Linardou H, Bafaloukos D and Papadimitriou C: Taxane resistance in breast cancer: mechanisms, predictive biomarkers and circumvention strategies. Cancer Treat Rev 38: 890-903, 2012.

46 Park SR, Kong SY, Nam BH, Choi IJ, Kim CG, Lee JY, Cho SJ, Kim YW, Ryu KW, Lee JH, Rhee J, Park YI and Kim NK: CYP2A6 and ERCC1 polymorphisms correlate with efficacy of $\mathrm{S}-1$ plus cisplatin in metastatic gastric cancer patients. Brit J Cancer 104: 1126-1134, 2011.

47 Kodera Y, Ito Y, Ohashi N, Nakayama G, Koike M, Fujiwara M and Nakao A: Impact of clinical response to first-line chemotherapy on gastric cancer patients treated with second-line and third-line chemotherapy. Hepato-gastroenterol 58: 1041-1045, 2011.

48 Nelsen CJ, Kuriyama R, Hirsch B, Negron VC, Lingle WL, Goggin MM, Stanley MW and Albrecht JH: Short term cyclin D1 overexpression induces centrosome amplification, mitotic spindle abnormalities and aneuploidy. J Biol Chem 280: 768$776,2005$.

49 Cai J, Wu J, Zhang H, Fang L, Huang Y, Yang Y, Zhu X, Li R and Li M: miR-186 downregulation correlates with poor survival in lung adenocarcinoma, where it interferes with cell-cycle regulation. Cancer Res 73: 756-766, 2013.

$50 \mathrm{Ju}$ X, Casimiro MC, Gormley M, Meng H, Jiao X, Katiyar S, Crosariol M, Chen K, Wang M, Quong AA, Lisanti MP, Ertel A and Pestell RG: Identification of a cyclin D1 network in prostate cancer that antagonizes epithelial-mesenchymal restraint. Cancer Res 74: 508-519, 2014.
$51 \mathrm{Xu}$ YY, Wu HJ, Ma HD, Xu LP, Huo Y and Yin LR: MicroRNA503 suppresses proliferation and cell-cycle progression of endometrioid endometrial cancer by negatively regulating cyclin D1. FEBS J 280: 3768-3779, 2013.

52 Gao P, Zhou GY, Liu Y, Li JS, Zhen JH and Yuan YP: Alteration of cyclin D1 in gastric carcinoma and its clinicopathologic significance. World J Gastroenterol 10: 2936-2939, 2004.

53 Squires MH, 3rd, Fisher SB, Fisher KE, Patel SH, Kooby DA, El-Rayes BF, Staley CA, 3rd, Farris AB, 3rd and Maithel SK: Differential expression and prognostic value of ERCC1 and thymidylate synthase in resected gastric adenocarcinoma. Cancer 119: 3242-3250, 2013.

54 McKay JA, Douglas JJ, Ross VG, Curran S, Loane JF, Ahmed FY, Cassidy J, McLeod HL and Murray GI: Analysis of key cellcycle checkpoint proteins in colorectal tumours. J Pathol 196: 386-393, 2002.

55 Kamoshida S, Matsuoka H, Shiogama K, Matsuyama A, Shimomura $\mathrm{R}$, Inada $\mathrm{K}$, Maruta $\mathrm{M}$ and Tsutsumi $\mathrm{Y}$ : Immunohistochemical analysis of thymidylate synthase, p16(INK4a), cyclin-dependent kinase 4 and cyclin D1 in colorectal cancers receiving preoperative chemotherapy: significance of p16(INK4a)-mediated cellular arrest as an indicator of chemosensitivity to 5-fluorouracil. Pathol Int 54: 564-575, 2004.

56 Zhong LP, Zhu DW, William WN, Jr., Liu Y, Ma J, Yang CZ, Yang X, Wang LZ, Li J, Myers JN, Lee JJ, Zhang CP and Zhang $\mathrm{ZY}$ : Elevated cyclin D1 expression is predictive for a benefit from TPF induction chemotherapy in oral squamous cell carcinoma patients with advanced nodal disease. Mol Cancer Ther 12: 1112-1121, 2013.
Received June 23, 2016

Revised September 25, 2016

Accepted September 28, 2016 